\title{
Reconstruction of a Raised Bog Development: Which Geochemical Parameters of Peat are the Most Convenient for Preliminary Analyses?
}

\author{
Monika Mętrak*, Malgorzata Suska-Malawska \\ Faculty of Biology, Biological and Chemical Research Centre, University of Warsaw \\ Żwirki i Wigury 101, 02-089 Warsaw, Poland
}

Received: 24 February 2014

Accepted: 11 December 2014

\begin{abstract}
Thanks to their unique physical, chemical, and biological properties, raised bogs are considered archives of past hydrological and vegetation changes, which in the case of ombrotrophic bogs may reflect alterations of paleoclimate. Detailed studies on the past transformations of bogs provide researchers with necessary knowledge to anticipate future changes of these ecosystems. The aim of this research was to find a good and easily obtainable paleoenvironmental proxy that can be used in preliminary studies with no need for advanced equipment and extra costs. For our studies three raised bogs were chosen, whose genesis and history have been comprehensively described by other authors according to micro- and macrofossil data. We performed chemical analyses on the samples from the cores taken from the described bogs. Obtained results were compared with accessible data on the bogs' development and underwent statistical analysis. In general, geochemical features of peat presented in this article corresponded well with the accessible micro- and marcofossil data, and content of non-hydrolysable lipids in peat turned out to be the best indicator of water level on the studied bogs.
\end{abstract}

Keywords: paleoenvironment, geochemical proxies, raised bog, heavy metals

\section{Introduction}

Thanks to their unique physical, chemical, and biological properties, peat, especially of ombrotrophic origin, can register and store information on events and processes that took place on the bog or in its surroundings. Among them, vegetation changes and water regime modifications which in turn can result from plant succession, natural or anthropogenous alterations of hydrological system or even climate changes [1-7].

In an anoxic, water-saturated, acidic environment of a raised bog both microflora and mesofauna are poorly devel-

*e-mail: mmetrak@biol.uw.edu.pl oped and rather inactive. These conditions, combined with the presence of various tannin-like polyphenolic compounds, significantly slow degradation processes and result in the high quality of chemical preservation of palynomorphs, macrofossils, and biopolymers in peat [1-7].

For paleoenvironmental reconstruction a multiproxy approach has been adopted, merging micro- and macrofossil record with various physical and geochemical parameters of peat. The most often measured parameters are degree of decomposition and degree of humification. Since the intensity of decomposition and humification increases with decreasing moisture of the bog surface, they can both be used as geochemical markers of past moisture changes and, in case of ombrotrophic bogs, of paleoclimate changes 
as well [7-11]. With the development of modern analytical methods, new paleoenvironmental proxies have come into play. Among them stable isotopes and chromatographically analyzed lipid composition of peat, both of which can provide detailed information on the development of bogs and allow us to infer about paleoclimate [12-20]. Multiproxy reconstructions of past transformations of bog ecosystems will help to predict their future changes caused by human impact and, in a longer time scale, by global warming. This in turn may prove crucial for raised bog preservation [21].

The aim of this research was to find a good and easy to obtain paleoenvironmental proxy by checking how well simple geochemical features of peat correspond to the macrofossil record. Such a proxy can be used in preliminary studies with no need for advanced equipment and extra costs. We paid special attention to rough lipid proxies - total extractable lipids and non-hydrolysable lipids. Moreover, we checked the amounts of chosen heavy metals stored in peat from the studied bogs.

\section{Materials and Methods}

Study Site

For our studies three raised bogs were chosen, whose genesis and history have been comprehensively described according to micro- and macrofossil data by Tomaszewska [22]. The bogs are located in the valley of the river Izera, in the Izerskie Mountains, SW Poland (Fig. 1). The Izerskie Mountains are part of a horst formed in the late Tertiary by uplift of an old denudation area. Although the outskirts of this denudation area were renewed by erosional activity of streams, its preservation (relics are visible on the hilltops) is a distinguishing feature of the Izerskie Mountains and provides favorable conditions for formation of peat deposits. Bogs are formed most often in the wide and flat parts of valleys in which tributaries join the main river (bogs $\mathrm{A}$ and $\mathrm{C}$ ). In the narrower parts of valleys slope bogs are formed, located above flooded areas (bog B) [23].
Bogs A (N: 50 $50.245^{\prime}$, E: $\left.15^{\circ} 22.612^{\prime}\right)$ and $\mathrm{B}(\mathrm{N}$ : $50^{\circ} 51.715^{\prime}$, E: $\left.15^{\circ} 19.248^{\prime}\right)$ were initially fed by underground waters, and bog C (N: 50 50.933', E: 15²2.156') was of fluviogenous origin. Currently, all the above-mentioned raised bogs have an ombrotrophic water regime [22]. According to Tomaszewska [22], bog C is the oldest, with a thill layer dated at 8,390 years BP. Bogs A and B started to develop in the same period - a thill layer of bog A was dated at 3,480 years BP and of bog B at 3,570 years BP.

In her work, Tomaszewska [22] divided cores from the bogs into homogenous zones, developed under the same water conditions. In the presented research, we also used this division. We took one core from each raised bog and sampled all layers distinguished by Tomaszewska [22]. Detailed cross-sections of the bogs were prepared by Tomaszewska and are available in her work [22].

\section{Chemical Analyses}

Organic matter properties of the samples were examined by measuring percentage content of mineral parts (MIN) according to Ostrowska et al. [24]; percentage degree of decomposition (DD) according to Okruszko [25]; percentage humic substances content (HS), including fractionation to humic and fulvic acids (HA and FA), according to Kononowa [26], and percentage total nitrogen content (TNC) with Kjeldahl method, according to Sapek and Sapek [27]. Moreover, total extractable lipids and non-hydrolysable lipids content were measured by performance of the following procedure. An air-dried peat sample was mixed with anhydrous $\mathrm{Na}_{2} \mathrm{SO}_{4}$ and extracted for six hours on a Soxhlet apparatus with a mixture of chlorophorm and methanol. The obtained extract was evaporated under vacuum and the container was carefully weighted. Total extractable lipids (TEL $\mathrm{mg} / \mathrm{g}$ dry weight) were calculated as a difference between the weight of a container with evaporated extract and its own weight. To examine the amount of non-hydrolysable lipids, previously acquired extract was saponified and the lipid part was separated in a separatory funnel with the use of diethylether. After evaporation of the lipid part, the con-

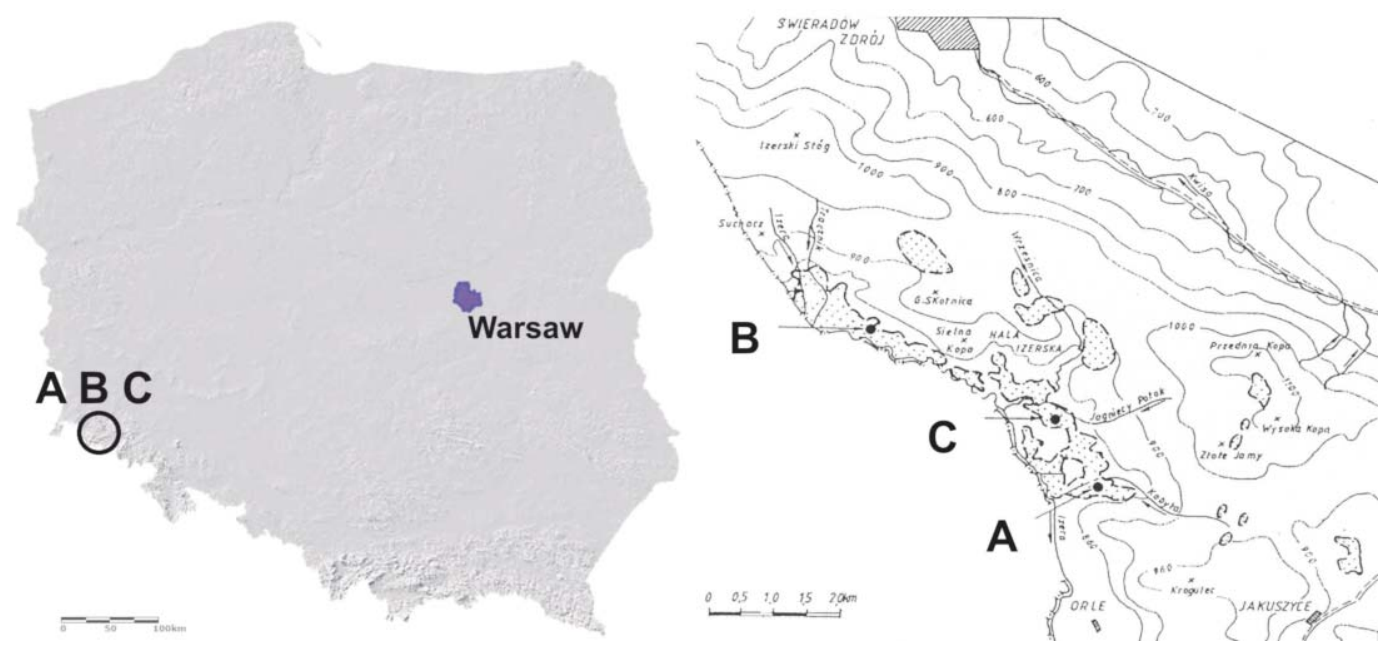

Fig. 1. Location of the studied raised bogs. Detailed map after Tomaszewska [22]. 
Table 1. Detailed characteristics of studied raised bogs.

\begin{tabular}{|c|c|c|c|c|c|c|c|c|c|c|}
\hline Name & $\begin{array}{l}\text { Depth } \\
{[\mathrm{cm}]}\end{array}$ & $\begin{array}{l}\text { Peat } \\
\text { type }\end{array}$ & Peat species & DD & $\begin{array}{l}\text { MIN } \\
{[\%]}\end{array}$ & $\begin{array}{l}\mathrm{TNC} \\
{[\%]}\end{array}$ & $\begin{array}{l}\text { HS } \\
{[\%]}\end{array}$ & $\begin{array}{l}\mathrm{HA} / \\
\mathrm{FA}\end{array}$ & $\begin{array}{c}\text { TLC } \\
\text { [mg/g d.w.] }\end{array}$ & $\begin{array}{c}\text { NHL } \\
\text { [mg/g d.w.] }\end{array}$ \\
\hline \multirow{7}{*}{ 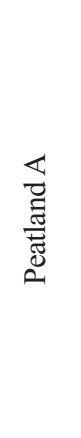 } & 5-12 & $\mathbf{R B}$ & cottongrass - Sphagnum peat & 1 & 7.80 & 1.58 & 14.90 & 1.41 & 139 & 3 \\
\hline & $25-75$ & $\mathrm{RB}$ & hollow Sphagnum peat & 1 & 1.49 & 0.73 & 8.33 & 1.03 & 72 & 6 \\
\hline & $90-100$ & RB & cottongrass - Sphagnum peat & 1 & 1.95 & 0.94 & $\begin{array}{c}10.74 \\
7.96\end{array}$ & 1.06 & 96 & 3 \\
\hline & $105-125$ & $\mathrm{RB}$ & hollow Sphagnum peat & 1 & 1.96 & 0.94 & 7.96 & 2.15 & 169 & 5 \\
\hline & $130-140$ & $\mathbf{R B}$ & pine peat & 2 & 3.00 & 2.46 & 11.05 & 1.61 & 99 & 4 \\
\hline & $150-190$ & RB & hummock Sphagnum peat & 2 & 1.96 & 1.13 & 19.08 & 2.27 & 105 & 5 \\
\hline & 190-200 & RB & pine peat & 2 & 6.93 & 1.14 & 17.92 & 1.48 & $\mathbf{x}$ & $\mathbf{x}$ \\
\hline \multirow{6}{*}{ 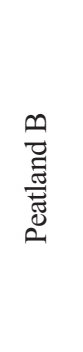 } & $5-12$ & $\mathrm{RB}$ & cottongrass - Sphagnum peat & 2 & 12.00 & 1.61 & 20.85 & 0.52 & 42 & 4 \\
\hline & $20-55$ & RB & hollow Sphagnum peat & 2 & 1.96 & 0.66 & 9.48 & 0.68 & 107 & 4 \\
\hline & $70-120$ & $\mathrm{RB}$ & hummock Sphagnum peat & 2 & 1.49 & 0.49 & 8.33 & 0.59 & 83 & 5 \\
\hline & $130-150$ & $\mathrm{RB}$ & cottongrass - Sphagnum peat & 1.5 & 1.00 & 0.81 & 9.24 & 0.75 & 129 & 8 \\
\hline & $150-175$ & RB & cottongrass - Sphagnum peat & 2.5 & 1.49 & 1.47 & 16.53 & 1.22 & 77 & 4 \\
\hline & 175-205 & RB & pine peat & 3 & 2.45 & 1.53 & 20.21 & 0.62 & 46 & 3 \\
\hline \multirow{5}{*}{ 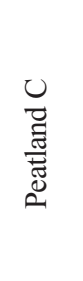 } & $10-60$ & $\mathrm{RB}$ & hummock Sphagnum peat & 1 & 2.49 & 0.87 & 5.49 & 1.73 & 64 & 7 \\
\hline & $150-200$ & $\mathrm{RB}$ & hummock Sphagnum peat & 1 & 0.99 & 0.68 & 7.47 & 1.82 & 59 & 9 \\
\hline & $270-320$ & $\mathrm{RB}$ & hollow Sphagnum peat & 1 & 1.00 & 0.57 & 8.84 & 0.88 & 57 & 6 \\
\hline & $350-400$ & RB & cottongrass - Sphagnum peat & 2 & 1.47 & 0.63 & 11.59 & 1.25 & 101 & 4 \\
\hline & $400-450$ & $\mathrm{~T}$ & Scheuchzeria peat & 2 & 2.94 & 1.42 & 35.66 & 0.60 & 133 & 6 \\
\hline
\end{tabular}

Not-bolded rows indicate high water levels during formation of a particular layer.

Bolded rows indicate low or changing water levels during the formation of a particular layer.

Water level was estimated according to Tomaszewska [22].

tainer was weighted and the content of non-hydrolysablelipids (NHL mg/g dry weight) was calculated as a difference between the weight of a container with evaporated extract and its own weight. All the reagents used were provided by Polish Chemical Reagents (POCH) and were of pure p.a. grade.

Heavy metals content in peat $(\mathrm{Pb}, \mathrm{Zn}, \mathrm{Cd})$ was measured by atomic absorption spectroscopy (AAS) after mineralization of ash in $20 \%$ solution of $\mathrm{HCl}$ at $130^{\circ} \mathrm{C}$ [27].

\section{Statistical Analyses}

For the assessment of variance in geochemical features in studied peat a primary component analysis (PCA) was performed. For further analyses peats were divided into two groups:

1) formed while the water level on the bog was high

2) formed while the water level on the bog was low or changing.

Differences between these two groups were assessed with the use of linear discriminant analysis (LDA) and the Kruskal-Wallis Test. Multivariate analyses were performed in CANOCO for Windows, Version 4.5 [28], and KruskalWallis tests in STATISTICA 10.

\section{Results}

\section{Raised Bog A}

Peat from the three deepest layers from this raised bog was formed mainly from higher plant remains, though the layer 150-190 cm was classified as hummock Sphagnum peat. In this case, apart from bryophytes, lots of cottongrass remains were present in the sediment. Chemical analyses showed a high degree of decomposition (about 40\%) and high content of mineral fraction in peats from these layers. They were also characterized by high content of humic substances, with prevailing humic acids, and quite high concentration of total nitrogen (Table 1). According to Tomaszewska [22], deposition of these layers took place in the period of fluctuating water level on the bog.

The next layer $(105-125 \mathrm{~cm})$ was formed from hollow Sphagnum peat, characterized by a lower degree of decomposition $(20 \%)$, lower content of mineral fraction, humic substances (still humic acids dominate), and total nitrogen (Table 1). As stated in Tomaszewska [22], this layer was formed after a significant increase of water level on the raised bog, which enabled expansion of the bryophyte component of this ecosystem. Therefore, this layer marks a substantial change in the development of the bog. 
The layers $90-100 \mathrm{~cm}$ and $25-75 \mathrm{~cm}$ are characterized by very similar geochemical features (moderate amount of humic substances with equal participation of humic and fulvic acids, relatively low total extractable lipids content), except the amount of non-hydrolysable lipids in peat. This parameter is two times higher in the deeper layer (Table 1). Despite the presented similarities, according to Tomaszewska [22] the upper layer deposited when the water level on the bog was relatively low.

The uppermost layer $(5-12 \mathrm{~cm})$, formed by Sphagnum, with high proportion of cottongrass remains, is characterized by a moderate degree of decomposition (20\%) and a high content of mineral fraction and humic substances (humic acids dominate) (Table 1). Tomaszewska [22] stated that this layer was formed after drainage of the bog in order to prepare it for tree planting.

\section{Raised Bog B}

The two deepest layers from this raised bog, pine peat layer $(175-205 \mathrm{~cm})$ and cottongrass - Sphagnum peat layer $(150-175 \mathrm{~cm})$, are characterized by the high degree of decomposition (about 60\%), high content of mineral fraction, and total nitrogen. These layers are also rich in humic substances, with high participation of fulvic acids (Table 1). The amount of total extractable lipids is rather low. As stated in Tomaszewska [22], these layers deposited while the bog was fed by relatively fertile surface waters.

The next three layers $(130-150 \mathrm{~cm}, 70-120 \mathrm{~cm}$, and 20$55 \mathrm{~cm}$ ) were formed mostly by Sphagnum peat, with low content of mineral fraction, total nitrogen, and humic substances (fulvic acids dominate), yet rich in lipids (both total extractable and non-hydrolysable Table 1). According to Tomaszewska [22], these layers represent the oligotrophic stage in bog development.

The uppermost layer $(5-12 \mathrm{~cm})$ is characterized by geochemical features typical of decomposed peat: high content of mineral fraction, total nitrogen, and humic substances (fulvic acids dominate). A degree of decomposition of this layer is about $30 \%$ (Table 1). Tomaszewska [22] stated that this bog was also drained for tree planting.

\section{Raised Bog C}

Peat from the deepest layer from this raised bog was formed mainly by Scheuchzeria remains and is characterized by a high degree of decomposition (45\%), high content of mineral fraction, humic substances (fulvic acids dominate), and total extractable lipids (Table 1). According to Tomaszewska [22] this layer was formed while the bog was fed by relatively fertile stream waters.

In the peat from the next layer $(350-400 \mathrm{~cm})$, all described parameters decrease (Table 1). As stated in Tomaszewska [22], this layer marks a significant change in the development of this bog, being the first layer of its stable oligotrophic stage. According to Tomaszewska, between $343 \mathrm{~cm}$ and $315 \mathrm{~cm}$ there was a layer of inorganic stream sediments deposited during a period of floods of a nearby stream. The beginning of this period was dated at 6,125 years BP and the end at 5,625 years BP [22]. However, in our core an exclusively mineral layer was absent.

The next three layers $(270-320 \mathrm{~cm}, 150-200 \mathrm{~cm}, 10-60$ $\mathrm{cm}$ ) are characterized by lower degrees of decomposition (about 10\%), lower content of total nitrogen, humic sub-

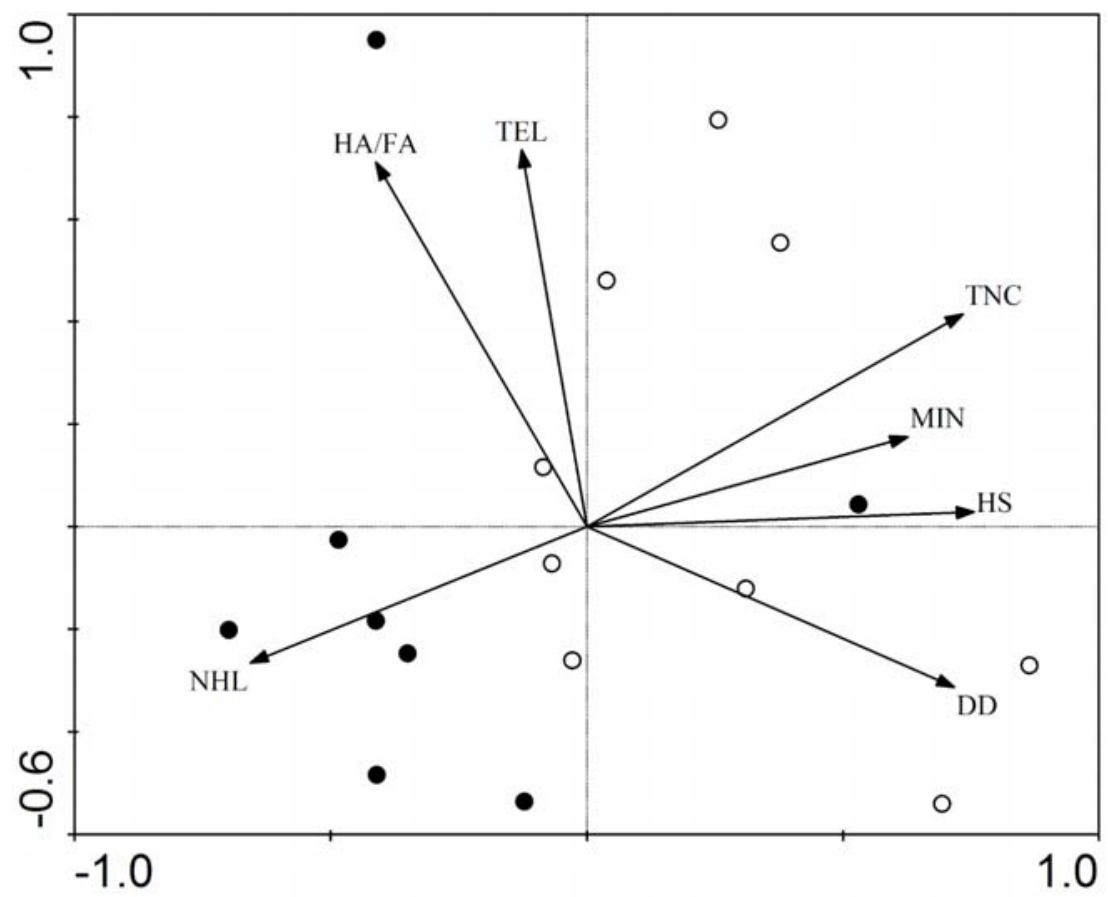

Fig. 2. PCA analysis showing variations in geochemical features in the studied samples. White circles indicate peats formed while the water level on the bog was low or changing, black circles indicate peats formed while the water level on the bog was high $\left(\lambda_{1}=0.376\right.$, $\left.\lambda_{2}=0.202, \lambda_{3}=0.137, \lambda_{4}=0.112\right)$. 
Table 2. Comparison of analyzed parameters between peat formed during periods of high water level and of low or changing water level.

\begin{tabular}{|l|c|c|c|c|c|c|c|c|}
\hline \multirow{2}{*}{ Water level } & Parameter & DD [\%] & MIN [\%] & TNC [\%] & HS [\%] & HA/FA & $\begin{array}{c}\text { TLC } \\
{[\mathrm{mg} / \mathrm{g} \text { d.w.] }}\end{array}$ & $\begin{array}{c}\text { NHL } \\
{[\mathrm{mg} / \mathrm{g} \text { d.w.] }}\end{array}$ \\
\hline \multirow{2}{*}{ High } & median & 1 & 1.49 & 0.77 & 8.33 & 0.96 & 77 & 6 \\
\cline { 2 - 10 } & range & $1-2$ & $0.99-2.94$ & $0.49-1.41$ & $5.49-35.66$ & $0.59-2.15$ & $57-169$ & $4-9$ \\
\hline \multirow{2}{*}{$\begin{array}{l}\text { Low or } \\
\text { changing }\end{array}$} & median & 2 & 2.20 & 1.30 & 15.71 & 1.24 & 99 & 4 \\
\cline { 2 - 10 }$y$ \\
\hline \multicolumn{2}{|l}{ Kruskal-Wallis Test (p-value) } & $0.0271^{* *}$ & 0.0608 & $0.0330^{* *}$ & $0.0077^{* *}$ & 0.8590 & 1.000 & $0.0008^{* *}$ \\
\hline
\end{tabular}

** highly significant results (d.w. - dry weight)

Table 3. Content of chosen heavy metals $(\mathrm{Pb}, \mathrm{Zn}, \mathrm{Cu})$ stored in peat from the studied raised bogs.

\begin{tabular}{|c|c|c|c|c|}
\hline Name & Depth $[\mathrm{cm}]$ & $\mathrm{Pb}[\mathrm{ppm}]$ & $\mathrm{Zn}$ [ppm] & $\mathrm{Cu}[\mathrm{ppm}]$ \\
\hline \multirow{7}{*}{$\begin{array}{c}\text { Raised } \\
\text { bog A }\end{array}$} & $5-12$ & 181 & 29 & 10 \\
\hline & $25-75$ & 38 & 10 & 2 \\
\hline & $90-100$ & 2 & 6 & 4 \\
\hline & $105-125$ & 4 & 7 & 3 \\
\hline & $130-140$ & 5 & 7 & 6 \\
\hline & $150-190$ & 5 & 7 & 4 \\
\hline & $190-200$ & 4 & 8 & 4 \\
\hline \multirow{6}{*}{$\begin{array}{c}\text { Raised } \\
\text { bog B }\end{array}$} & $5-12$ & 487 & 24 & 20 \\
\hline & $20-55$ & 9 & 23 & 2 \\
\hline & $70-120$ & 2 & 6 & 2 \\
\hline & $130-150$ & 3 & 6 & 4 \\
\hline & $150-175$ & 3 & 6 & 4 \\
\hline & $175-205$ & 1 & 5 & 4 \\
\hline \multirow{5}{*}{$\begin{array}{l}\text { Raised } \\
\text { bog } C\end{array}$} & $10-60$ & 31 & 14 & 4 \\
\hline & $150-200$ & 1 & 9 & 1 \\
\hline & $270-320$ & 6 & 6 & 2 \\
\hline & $350-400$ & 1 & 8 & 2 \\
\hline & $400-450$ & 2 & 10 & 3 \\
\hline
\end{tabular}

stances (humic acids dominate), and total extractable lipids, yet they contain relatively high amounts of nonhydrolysable lipids (Table 1).

\section{Statistical Analyses}

Differences in geochemical characteristics of peats deposited under moist and dry conditions (high and low or changing water level on the bog) are shown on the PCA diagram (Fig. 2). Peats formed while the water level on the bogs was high constitute a distinguished group in the left lower part of the diagram. Two scattered points from this category are a sample characterized by the highest observed content of total extractable lipids (left upper part) and a sample characterized by the highest observed content of humic substances (in the middle of the right part of the diagram).

Further analyses showed that peats formed while the water level on the bogs was high were characterized by a significantly higher content of non-hydrolysable lipids $(p=0.0008)$; a significantly lower content of humic substances $(\mathrm{p}=0.0077)$ and total nitrogen $(\mathrm{p}=0.0330)$; and higher degree of decomposition $(\mathrm{p}=0.0271)$ in comparison to peats formed while the water level on the bogs was low or changing (Table 2).

The best discriminating parameter seems to be nonhydrolysable lipids content, characterized by the lowest $\mathrm{p}$ value in the Kruskal-Wallis Test $(\mathrm{p}=0.0008)$. This observation is confirmed by LDA analysis, which showed that nonhydrolysable lipids content explains $56 \%$ of variation observed between a group of peats formed under moist conditions and a group of peats formed under dry conditions $\left(\lambda_{1}=0.559, \lambda_{2}=0.441, \lambda_{3}=0.000, \lambda_{4}=0.000, \mathrm{p}=0.002\right)$.

\section{Heavy Metals}

For all of the studied bogs, the highest amounts of heavy metals were detected in the uppermost layers (Table 3 ). The surface layers from bogs A and B were significantly richer in metal ions (especially lead) in comparison to the surface layer from bog C.

\section{Discussion}

All geochemical features of peat chosen in this study might be viewed as markers of organic matter transformations. These transformations may result from habitat alterations, such as shifts in water level and temperature, which directly influence decomposition processes on the bog. They may also be influenced by vegetation changes. Modification of peat-forming species composition alters chemical composition of plant biomass entering the bog, and eventually affects decomposition processes (Fig. 3).

Both habitat and vegetation alterations can be caused either by autogenous (e.g. plant succession) or allogenous (e.g. changes of water regime in the catchment, weather phenomena) processes [2]. As far as mountainous raised 


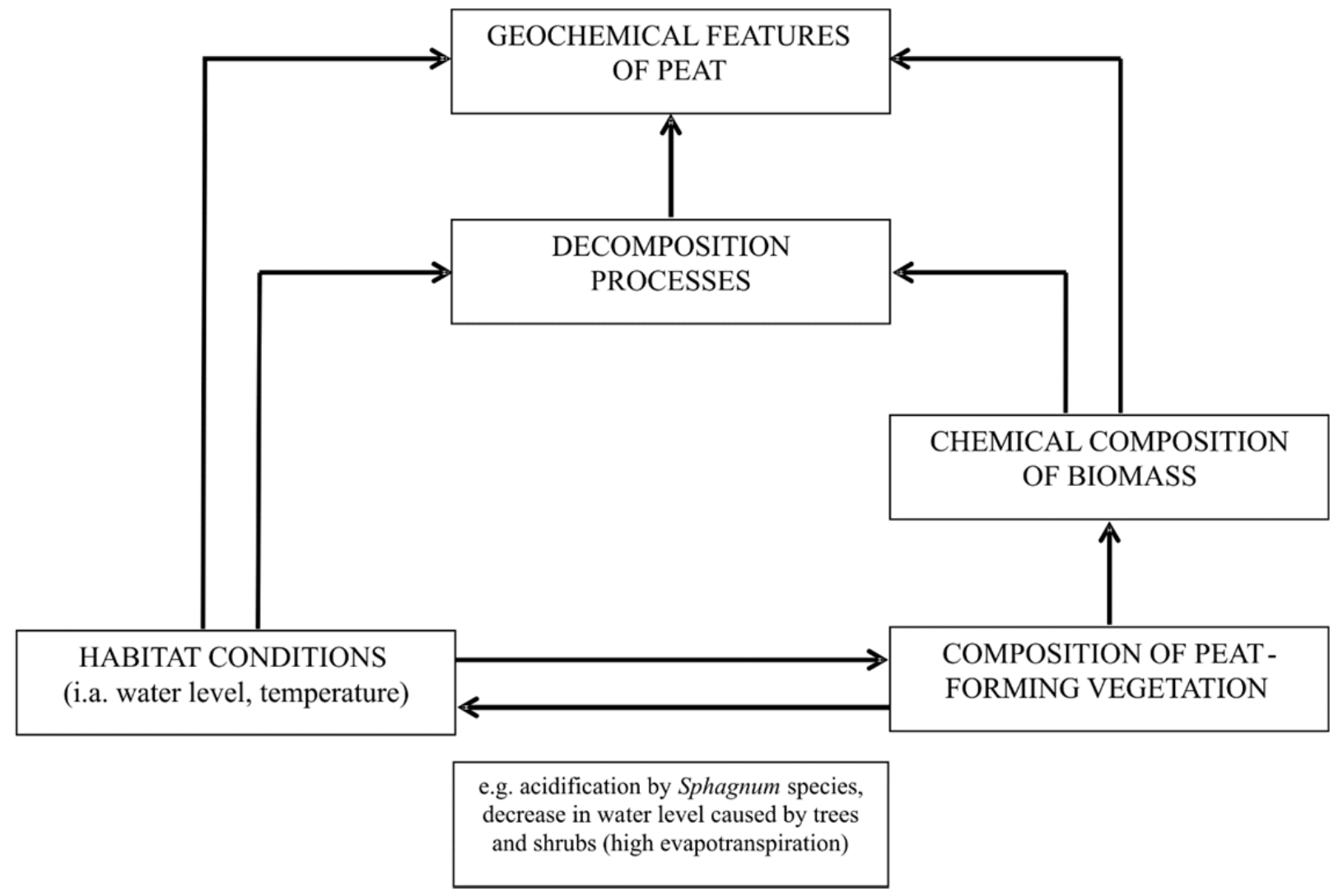

Fig. 3. Factors influencing transformations of organic matter in peat.

bogs are concerned, one of the most important allogenous factors is activity of streams. In the valley of the Izera River, its tributaries are meandering freely, cutting through peat deposits and reaching periglacial eroded materials at the bottom of organic sediments. These materials might be further eroded, leading to breaking of huge peat blocks from the deposit. Such processes are the most intense during periods of high water level in the streams [23, 29].

According to these facts, there are two main drivers of organic matter transformations in the bog:

1) habitat conditions during deposition of particular layers and, resulting from them,

2) species composition of peat-forming plants.

In the case of sedentary sediments, these factors are interrelated and their impact on decomposition processes cannot be clearly distinguished (Fig. 3).

The most widely used marker of organic matter transformations is a degree of decomposition measured as a ratio of decomposed amorphous matter to undecomposed peat. According to Tobolski [4], the amount of amorphous matter, rather than being a function of time, is driven by bog hydrology. Consequently, it can be used as a geochemical marker of past moisture changes in the surface of a bog. In the case of ombrogenic bogs the degree of decomposition also can be used for assessment of paleoclimate changes, following a rule that the drier the conditions, the higher the degree of decomposition, because additional oxygen access to the sediments enables quick mineralization of organic matter [2, 30-33].
According to our study, the degree of decomposition was one of the geochemical parameters that significantly differentiated between peats formed under moist and under dry conditions (high and low or changing water level on the bog). This parameter is also influenced by chemical composition of biomass forming the sediments. Peats formed mostly from bryophytes, especially Sphagnum remains, are more resistant to decomposition than peats formed from higher plant biomass. Bryophyte tissues are less prone to decomposition because of specific primary and secondary metabolites (i.e. polyphenols, Sphagnum acid) and C:P ratio higher than in tracheophytes [34-36]. The degree of decomposition of studied peats was also affected by time, being visibly higher in the deepest layers.

As an additional assessment of intensity of decomposition processes on the bog, we used percentage content of mineral parts in peat. This usually follows a simple rule that the more decomposed the peat, the higher the content of mineral fraction. We observed this tendency in our study, though the $\mathrm{p}$ value for comparison between peats formed under moist and under dry conditions was slightly above 0.05 (probably due to a disproportional increase in mineral fraction in peat from bottom and surface layers of the studied bogs). In the bottom layers it was the effect of an inflow of surface waters to the bogs and in the surface layers it was caused by adaptation of bogs to tree planting [22].

Just like the decomposition degree, total nitrogen content in the studied peats significantly differentiated between peats formed under moist and under dry conditions. Yet the 
nitrogen content was a result of biomass chemical composition rather than of decomposition itself. Tissues of higher plants contain significantly more total nitrogen than bryophytes [35, 37, 38]. Hence, we observed the highest total nitrogen amounts in peat rich with the remains of pine wood and cottongrass. In case of the studied bogs, the occurrence of both pines and cottongrass was an indicator of water level decrease and dry habitat conditions [22].

Transformations of organic matter in the bog are also reflected by a degree of humification. This parameter is usually considered a percentage participation of humic substances in organic matter. The intensity of humification increases with decreasing moisture of the bog surface [7-9, $30,39,40]$.

In the case of ombrotrophic bogs, we can use this relationship to infer about past climatic conditions. Though it is worth remembering that the degree of humification also depends strongly on the source of plant material [11, 41].

In our studies the simplest indicator of humification processes, i.e. overall humic substances content, clearly distinguished a group of peats formed under dry conditions from a group formed under moist conditions. Inconclusive results obtained for our indicator of humification degree (HA/FA) were probably caused by the method's shortcomings, which included breakdown of humic acids into fulvic acids [42, 43], causing artificial changes in an examined ratio.

Lipid fraction of organic sediments, including peat, can be very useful as far as paleoenvironmental reconstructions are concerned. Lipids provide researchers with information on the nature and abundance of organic matter sources and on reactions occurring after deposition of plant biomass. Therefore, detailed studies on qualitative and quantitative lipid composition in organic sediments make inferences about pasts environmental conditions possible $[3,8,10,12$, $13,16-20,44]$.

Lipid indicators used in this study were rather rough and comprised content of total extractable lipids and of non-hydrolysable lipids in peat. Though we initially supposed, that the total extractable lipids will be more abundant in peat deposited under dry conditions and therefore richer in higher plants remains, this indicator turned out to be indiscriminate.

On the other hand, amounts of non-hydrolysable lipids in peat formed under dry and under moist conditions differed significantly ( $\mathrm{p}$ value 0.0008 ) and explained $56 \%$ of variation observed between these two groups of peats. High content of non-hydrolysable lipids is typical for bryophytes, especially Sphagnum mosses, which are particularly rich in sterols [34, 36]. Therefore, high-amounts of nonhydrolysable lipids are typical for slightly decomposed and highly acidic bryophyte peat. Such peat develops while the water level on the bog is high and stable, hence content of non-hydrolysable lipids in peat can be used to distinguish between peats formed under dry and under moist conditions.

As far as heavy metals are concerned, we observed an increase of their concentrations in the uppermost layers of the studied bogs. Though the Sudety Mountains are well known as a site of intensive, historical ore mining and smelting, there are only poor deposits of tin ore and cobalt minerals in the Izerskie Mountains, located in the valley of the Kwisa River and separated from our study areas by the Wysoki Grzbiet Range [45]. Hence, we assumed that the observed heavy metals deposits are of current origin (second half of the $20^{\text {th }}$ century). They were probably transported there as transboundary pollutants from smelters and plants in the Czech Republic and Germany. High heavy metals concentrations in the uppermost layers of peat are also related to drainage of bogs in order to prepare them for tree planting. Surface layers of peat are characterized by high volume density, since lowering the water level on the bogs caused intense mineralization. Therefore, the amount of metal ions counted for the unit of mass will be relatively higher $[6,46]$. This process is clearly visible on the raised bogs $\mathrm{A}$ and $\mathrm{B}$, which were subjected to drainage and are characterized by much higher concentrations of heavy metals in the surface layers than bog $\mathrm{C}$.

\section{Conclusions}

Simple geochemical features of peat presented in this article usually corresponded well to accessible micro- and marcofossil data. Content of non-hydrolysable lipids in peat turned out to be the best indicator of water level on the studied bogs. Therefore, it may be employed to infer about paleoenvironmental changes and, in the case of ombrotrophic bogs, alterations of paleoclimate.

\section{References}

1. BLACKFORD J., PAYNE R.J. Peat humification and climate change: a multi-site comparison from mires in south-east Alaska. Mires and Peat 3, 2008 [www.mires-and-peat.net].

2. LAVOIE M., PELLERIN S., LAROCQUE M. Examining the role of allogenous and autogenous factors in the longterm dynamics of a temperate headwater peat land (southern Québec, Canada). Palaeogeogr. Palaeocl. 386, 336, 2013.

3. LÓPEZ-DÍAS V., URBANCZYK J., BLANCO C.G., BORREGO A.G. Biomarkers as paleoclimate proxies in peat lands in coastal high plains in Asturias, N Spain. Int. J. Coal. Geol. 116-117, 270, 2013.

4. TOBOLSKI K. Guide to identification of peats and lake sediments. PWN, Warszawa, 2000.

5. TOBOLSKI K. Geological criteria in research on reservoirs of biological accumulation. Regionalny Monitoring Środowiska Przyrodniczego 5, 119, 2004.

6. TOBOLSKI K. Paleolimnology in the context of the biotic zone. Studia Limnologica et Telmatologica, pp 43-50, 2007.

7. ZACCONE C., CASIELLO G., LONGOBARDI F., BRAGAZZA L., SACCO A., MIANO T.M. Evaluating the 'conservative' behavior of sTable isotopic ratios $\left(\delta^{13} \mathrm{C}, \delta^{15} \mathrm{~N}\right.$, and $\left.\delta^{18} \mathrm{O}\right)$ in humic acids and their reliability as paleoenvironmental proxies along a peat sequence. Chem. Geol. 285, 124, 2011.

8. CHAMBERS F.M., BOOTH R.K., DE VLEESCHOUWER F., LAMENTOWICZ M., LE ROUX G., MAUQUOY D., NICHOLS J.E., VAN GEEL B. Development and refinement of proxy-climate indicators from peat. Quatern. Int. 268, 21, 2012. 
9. KLAVINS M., SIRE J., PURMALIS O., MELECIS V. Approaches to estimating humification indicators for peat. Mires and Peat 3, 2008 [www.mires-and-peat.net]

10. WANG R.L., BRASSELL S.C., SCARPITTA S.C., ZHENG M.P., ZHANG S.C., HAYDE P.R., MUENCH, L.M. Steroids in sediments from Zabuye Salt Lake, western Tibet: Diagenetic, ecological or climatic signals? Org. Geochem. 35, 157, 2004.

11. YELOFF D., MAUQUOY D. The influence of vegetation composition on peat humification: implications for paleoclimatic studies. Boreas 35, 662, 2006.

12. ANDERSSON R.A., MEYERS P.A. Effect of climate change on delivery and degradation of lipid biomarkers in a Holocene peat sequence in the Eastern European Russian Arctic. Org. Geochem. 53, 63, 2012.

13. HUANG X., XUE J., WANG X., MEYERS P.A., HUANG J., XIE S. Paleoclimate influence on early diagenesis of plant triterpenes in the Dajiuhu peat land, central China. Geochim. Cosmochim. Ac. 123, 106, 2013.

14. LI H.-C., LIEW P.-M., SEKI O., KUO T.-S., KAWAMURA K., LIANG-CHI WANG L.-C., LEE T.-Q. Paleoclimate variability in central Taiwan during the past $30 \mathrm{Kyrs}$ reflected by pollen, $\mathrm{d}^{13} \mathrm{C}$ TOC, and n-alkane- $\mathrm{dD}$ records in a peat sequence from Toushe Basin. J. Asian Earth Sci. 69, 166, 2013.

15. MARGALEF O., CAÑELLAS-BOLTÀ N., PLA-RABES S., GIRALT S., PUEYO J.J., JOOSTEN H., RULL V., BUCHACA T., HERNÁNDEZ A., VALERO-GARCÉS B.L., MORENO A., SÁEZ A. A 70,000 year multiproxy record of climatic and environmental change from Rano Aroi peat land (Easter Island). Global Planet. Change 108, 72, 2013.

16. MCKIRDY D.M., THROPE C.S., HAYNES D.E., GRICE K., KRULL E.S., HALVERSON G.P., WEBSTER L.J. The biogeochemical evolution of the Coorong during the mid- to late Holocene: An elemental, isotopic and biomarker perspective. Org. Geochem. 41, 96, 2010.

17. PANCOST D.R., MCCLYMONT E.L., BINGHAM E.M., ROBERTS Z., CHARMAN D.J., HORNIBROOK E.R.C., BLUNDELL A., CHAMBERS F.M., LIM K.L.H., EVERSHED R.P. Archeol as methanogen biomarker in ombrotrophic bods. Organic Chemistry 42, 1279, 2011

18. PU Y., NACE T., MEYERS P.A., ZHANG H., WANG Y., ZHANG C.L., SHAO X. Paleoclimate changes of the last 1000 yrs on the eastern Qinghai-Tibetan Plateaurecorded by elemental, isotopic, and molecular organic matter proxies in sediment from glacial Lake Ximencuo. Palaeogeogr. Palaeocl. 379-380, 39, 2013.

19. ZHENG Y., ZHOU W., MEYERS P.A. Proxy value of nalkan-2-ones in the Hongyuan peat sequence to reconstruct Holocene climate changes on the eastern margin of the Tibetan Plateau. Chem. Geol. 288, 97, 2011.

20. WANG H., HONG Y., LIN Q., HONG B., ZHU Y., WANG Y., XU H. Response of humification degree to monsoon climate during the Holocene from the Hongyuan peat bog, eastern Tibetan Plateau. Palaeogeogr. Palaeocl. 286, 171, 2010.

21. JOOSTEN H., CLARKE D. Wise Use of Mires and Peat lands. International Mire Conservation Group and International Peat Society. 2002.

22. TOMASZEWSKA K. Development history of the chosen raised bogs in the Izerskie Mountains, including anthropogenic vegetation changes. Wydawnictwo Akademii Rolniczej, Wrocław, 2004.
23. POTOCKA J. Preservation degree, geomorphological and hydrological conditions of location of raised bogs in the Izerskie Mountains. Przyroda Sudetów Zachodnich 3, 35, 2000.

24. OSTROWSKA A., GAWLIŃSKI S., SZCZUBIAŁKA Z. Methods of analysis and assessment of soil and plant biomass properties. Instytut Ochrony Środowiska, Warszawa, 1991.

25. OKRUSZKO H. Principles of organic soils division. Wiadomości Instytutu Melioracji i Użytków Zielonych 12, 19, 1974.

26. KONONOWA M.M. Soil organic matter, its structure, properties and methods of analysis. PWRiL, Warszawa, 1968.

27. SAPEK A., SAPEK B. Methods of chemical analysis of organic soils. Materiały instruktażowe Instytutu Melioracji i Użytków Zielonych. Wydawnictwo IMUZ, Falenty, 1997.

28. BRAAK TER C.J.F., SMILAUER P. CANOCO Reference Manual and User's Guide to CANOCO for Windows: Software for Canonical Community Ordination (version 4). Microcomputer Power, Ithaca, New York, USA, 1998.

29. KASPRZAK M. Geomorphological and ecological effects of flooding. In: Extraordinary natural events in the Lower Silesia region and their effects (P. Migoń, Ed.), UWr, Wrocław, pp. 161-174, 2010.

30. BUNBURY J., FINKELSTEIN S.A., BOLLMANN J. Holocene hydro-climatic change and effects on carbon accumulation inferred from a peat bog in the Attawapiskat River watershed, Hudson Bay Lowlands, Kanada. Quaternary Res. 78, 275, 2012.

31. DORREPAAL E., AERTS R., CORNELISSEN J.H.C., CALLAGHAN T.V., VAN LOGTESTIJN R.S.P. Summer warming and increased winter snow cover affect Sphagnum fuscum growth, structure and production in a subarctic bog. Glob. Change Biol. 10, 93, 2004.

32. KLEIN E.S., BOOTH R.K., YU Z., MARK B.G., STANSELL N.D. Hydrology-mediated differential response of carbon accumulation to late Holocene climate change at two peat lands in Southcentral Alaska. Quaternary Sci. Rev. 64, 61, 2013.

33. NOVAK M., BRIZOVA E., ADAMOVA M., ERBANOVA L., BOTTRELL S.H. Accumulation of organic carbon over the past 150 years in five freshwater peat lands in western and central Europe. Sci. Total Environ. 390, 425, 2008.

34. BAAS M., PANCOST R., VAN GEEL B., SINNINGHE DAMSTE J.S. A comparative study of lipids in Sphagnum species. Org. Geochem. 31, 535, 2000.

35. GLIME J.M. Bryophyte ecology. Published on-line at http://www.bryoecol.mtu.edu, 2006.

36. TAHVANAINEN T., HARAGUCHI A. Effect of $\mathrm{pH}$ on phenol oxidase activity on decaying Sphagnum mosses. Eur. J. Soil Biol. 54, 41, 2013.

37. AERTS R., VERHOEVEN J. T. A., WHIGHAM D. F. Plant-mediated controls on nutrient cycling in temperate fens and bogs. Ecology 80, 2170, 1999.

38. TURETSKY M. R. The role of bryophytes in carbon and nitrogen cycling. Bryologist 106, 395, 2003.

39. LOISEL J., GARNEAU M. Late Holocene paleoecohydrology and carbon accumulation estimates from two boreal peat bogs in eastern Canada: Potential and limits of multiproxy archives. Palaeogeogr. Palaeocl. 291, 493, 2010.

40. ZACCONE C., SANEI H., OUTRIDGE P.M., MIANO T.M. Studying the humification degree and evolution of peat down a Holocene bog profile (Inuvik, NW Canada): A petrological and chemical perspective. Org. Geochem. 42, 399, 2011. 
41. KLAVINS M., PURMALIS O. Properties and structure of raised bog peat humic acids. J. Mol. Struct. 1050, 103, 2013.

42. CASELDINE C.J., BAKER A., CHARMAN D.J., HENDON D. A comparative study of optical properties of $\mathrm{NaOH}$ peat extracts: implications for humification studies. The Holocene 10, 649, 2000.

43. STEVENSON F.J. Humus Chemistry: Genesis, Composition, Reactions. John Wiley, New York, 1982.

44. DISNAR J.R., STEFANOVA M., BOURDON S., LAGGOUN-DEFARGE F. Sequential fatty acid analysis of a peat core covering the last two millennia: Diagenesis appraisal and consequences for paleoenvironmental reconstruction. Org Geochem 36, 1391, 2005.

45. MADZIARZ M. Historical ore mining sites in Lower Silesia (Poland) as geo-tourism attraction. Acta Geoturistica 4, 15, 2013.

46. SMIEJA-KRÓL B., FIAŁKIEWICZ-KOZIEŁ B., SIKORSKI J., PALOWSKI B. Heavy metal behaviour in peat - A mineralogical perspective. Sci. Total Environ. 408, 5924, 2010. 
